\title{
The Evolution of the Bacterial Community Between Hospitals, Wastewater Treatment Plants and the Aquatic Environment
}

\author{
ALINA ROXANA BANCIU1 ${ }^{1}$, LUCIAN IONESCU ${ }^{1}$, DANIELA LILIANA IONICA ${ }^{1}$, \\ MONICA ALEXANDRA VAIDEANU ${ }^{1,2}$, SIMONA MARIANA CALINESCU ${ }^{1}$, \\ MIHAI NITA-LAZAR ${ }^{*}$, LUMINITA MARUTESCU ${ }^{3}$, MARCELA POPA ${ }^{3}$, \\ MARIANA CARMEN CHIFIRIUC ${ }^{3}$ \\ ${ }^{1}$ National Research and Development Institute for Industrial Ecology-ECOIND, 71-72 Drumul Podu Dambovitei, 060652, \\ Bucharest, Romania \\ ${ }^{2}$ University of Bucharest, Faculty of Chemistry, 4-12 Regina Elisabeta Blvd., 030018, Bucharest, Romania \\ ${ }^{3}$ Research Institute of the University of Bucharest, 90 Soseaua Panduri, 050663, Bucharest, Romania
}

\begin{abstract}
Wastewater treatment plants are major interface between rural and urban activities and the natural environment with problems relating to the survival and transmission of the fecal bacteria into streams and rivers. The main goal of this paper was to showed the impact of WWTPs on fecal populations bacteria and their dissemination into the aquatic ecosystems. The sampling campaigns were conducted in 2019 where the hospital and WWTPs wastewater from three cities from the southeastern part of Romania and the surface water of their emissaries were trimestral collected. The quantitative and qualitative analysis of total and fecal coliforms indicated the efficiency of wastewater treatment processes but at the same time, the contribution of contamination with hospital effluents has been demonstrated. Also, the microbiological results showed the selectivity of the destruction of fecal coliform bacteria between wastewater and surface water.
\end{abstract}

Keywords: resistance bacteria, pollution, hospital effluents, WWTP

\section{Introduction}

The water cycle from catchment to discharge is a sector that involves important investments, operation and maintenance costs. In particular, sewage treatment is a challenge for governments because they are having to consider economic, environmental and social aspects. The EU (European Union) Directive 91/271/EEC sets the requirements that all urban areas must have wastewater treatment infrastructures to reduce the environmental impact of treated wastewater in water bodies. [1]. Wastewater treatment plants are major interface between rural and urban activities and the natural environment, but the studies are based in particular on the elimination of chemical pollutants and less on microbiological contamination.

There is a lot of controversy over the survival and transmission of the fecal coliform group into water bodies. The control of fecal pollution sources is a reliable action to understand the outcome of microorganisms with potential health impact in most ecosystems. Organisms in this type of pollution are potentially pathogenic or pathogenic bacteria with gastro-intestinal habitat that can trigger infectious processes in the human body [2,3].

The biggest concern associated with microbial pollution in the risk of human health and livestock related illness after exposure to contaminated water sources. Increasing pressure on existing Wastewater Treatment Plants (WWTPs) has led to environmental discharge of microbiological inadequately treated effluent from WWTPs results in the release of large amounts of organic matter and nutrients negative impacting on the surrounding environment as well as human health [4].

*email: mihai.nita@incdecoind.ro 
Wastewater treatment plants are major interface between rural and urban activities and the natural environment. WWTP treated effluents have been a significant source of pathogenic bacteria release into downstream environment. Hospitals are the major hot spot of pathogenic bacteria and thus facilitate this spread [5].

Hospital effluent with its high content of multidrug resistant (MDR) enterobacteria and the presence of enteric pathogens could pose a major problem for the community [6].

In this paper, we showed the impact of WWTP on microbial population and their dissemination into the environment.

\section{Materials and methods}

The sampling campaigns were conducted in 2019 where the municipal wastewater (influent and effluent WWTPs) from three cities (Iași, Galați and Bucharest) located in the southeastern part of Romania were trimestral collected. At the same time, surface water from Bahlui, Siret and Dambovita emissaries were taken from upstream and downstream locations from the municipal WWTP locations. The sampling was performed according to standard method ISO 19458 also described in the article of Catrangiu et al. [7,8] and quantitative and qualitative bacteriological indicators were analyzed. The density of coliform bacteria and Escherichia coli were simultaneous detected by the most probable number technique [9] using Colilert-18 (IDEXX) based on the bacterial propriety to metabolize the orto-nitrophenyl-beta-D-galactopyranoside (ONPG) and 4-methyl-umbelliferyl (MUG) as a carbon source with a chromogenic reaction as result. The bacterial strains identification was performed with automatic Omnilog system based on their metabolic specificity.

\section{Results and discussions}

The sampling locations were chosen based on the fact that those cities have important industrial and medical activities that could subsequently influence the potential pathogenic microbiological profile on natural aquatic ecosystems. The WWTPs were designed to process a large volume of wastewaters from the unitary sewage system of each city including from the hospitals. Each WWTP discharged in their natural emissaries: Bahlui (Iasi), Siret (Galati) and Dambovita (Bucharest) which are tributaries of the Danube River bringing a significant pathogen contribution.

The hospital contamination contribution has been shown to be significant in terms of coliform bacterial value (Figure 1a). Also, the WWTP influents registered high values of the total coliforms and thermotolerant (fecal) bacteria. Accumulation of municipality wastewater determined a high value ( $28 \times 10^{6} \mathrm{CFU} / 100 \mathrm{~mL}$ for total coliforms and $82 \times 10^{5}$ for fecal coliforms) of WWTP influent. In both cases of total and fecal coliforms (Figure 1a, b), the bacterial densities showed a similar pattern of total and fecal coliforms. It can be observed that out of total coliform bacteria a proportion greater than $50 \%$ was represented by fecal coliform bacteria (Figure 1).

The efficiency of WWTPs was demonstrated by the significant decrease of coliform bacteria load (up to $90 \%$ ) in effluent compared to WWTP influent. The ratio between total and fecal coliform bacteria in upstream and downstream surface water indicated specific changes in the structure of bacterial populations argued for dilution and optimal survival conditions.

Also, it can be observed that out of total coliform bacteria a proportion greater than $50 \%$ was represented by fecal coliform bacteria in the influents of WWTPs and hospitals (Figure 1).

Considering the difference of values between the bacterial densities between the influent and the effluent, the efficiency of the treatment plants was demonstrated, so that in the surface water upstream, the number of coliform bacteria significantly decreases. 


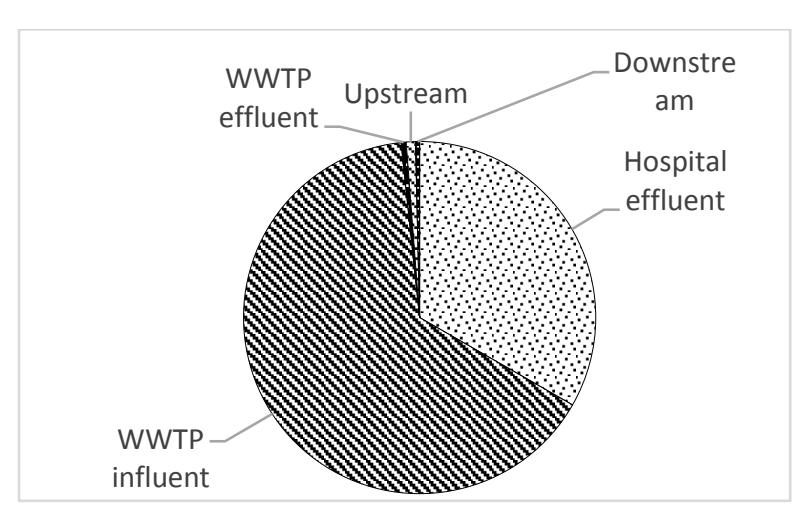

a. Total coliform

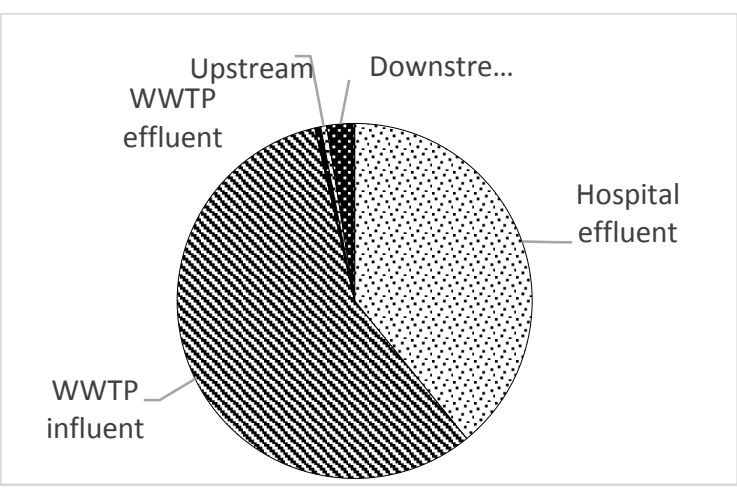

b. Fecal coliform

Figure 1. Densities (CFU/100mL) of total coliform (a) and fecal coliform (b) from wastewater and surface water samples. The results were based on the triplicates of assays

Hospital effluent presented closely values of bacterial density with the WWTP influent values, proving the fact that microbiological reduction was nonselective without reducing the fecal group.

The results of fecal bacteria rapport from upstream indicated a possible contamination of anthropogenic source.

Comparing the coliforms densities values between total coliforms and fecal coliforms in downstream and upstream, it can be observed a dynamic of fecal population, such that the fecal coliforms recorded a higher value in downstream (Figure 2). The chemical compounds resulting from the wastewater treatment process, eliminated by WWTP effluent selectively influence the density of fecal bacteria.

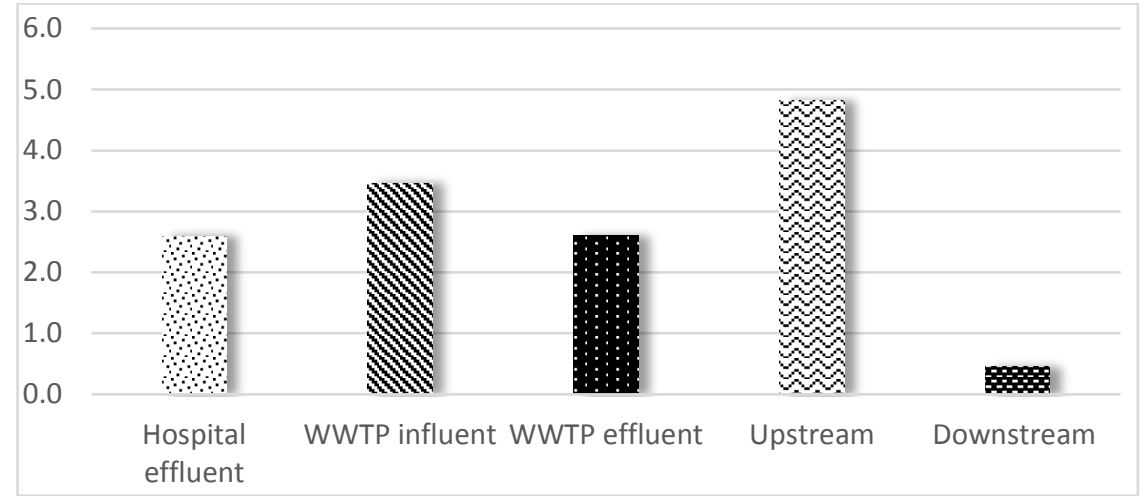

Figure 2. The changes of the microbial populations' structure based on the rapport between total coliform/ fecal coliform densities.

\section{Conclusions}

The intensified anthropic activities in the last decades have caused worldwide changes in ecological systems including in aquatic systems [10]. The waterborne pathogenic bacteria, especially the enteric bacteria of human fecal origin, have become currently a global public health issue [11].

The results of microbiological analysis on wastewater of hospital and WWTPs samples and surface water from southeastern of Romania indicated the influence of the water discharged from the hospital on the WWTPs influent and the efficiency of wastewater treatment processes.

Also, there were observed the contribution of anthropogenic activities by increasing the density of fecal bacteria downstream from upstream. The selectivity of the destruction of fecal coliform bacteria was demonstrated by comparing the densities of total and fecal coliform bacteria in wastewater and surface water. The impact of chemical compounds on microorganisms in polluted areas [12] was highlighted by the dynamics of fecal coliform bacteria populations in surface water, so that in upstream was recorded an increasing of fecal density influenced by the chemical factors from WWTPs. 
Acknowledgement: This work was financially supported by grant PN-III-P4-ID-PCCF-2016-011 (contract no. 10/2018) from the Romanian National Authority for Scientific Research and Innovation CNCS/CCCDI-UEFISCDI.

\section{References}

1.HERNANDEZ-CHOVER, V., BELLVER-DOMINGO, A., HERNANDEZ-SANCHO, F., Efficiency of wastewater treatment facilities : The influence of scale economies, J. Environ. Manage. 228, 2018, 77-84.

2.BANCIU. (CATRANGIU), A., NICULESCU, D., NITA-LAZAR, M., LUCACIU, I., STOICA, C., MIHAESCU, G., Potentialyy pathogenic and antibiotic resistant bacteria in the Danube Delta aquatic ecosystem, J. Environ. Prot. Ecol., 17(1), 2016, 127-135.

3.LAZAR, M.N., GHEORGHE, S., ANGHELACHE, A., BANCIU, A., STOICA, C., LUCACIU, I., Modulation of the bacteria defense mechanisms by various chemical structures, Rev. Chim., 67(8), 2016, 1454-1457.

4.NAIDOO, S., OLANIRAN, A.O., Treated Wastewater Effluent as a Source of Microbial Pollution of Surface Water Resources, Int. J. Environ. Res. Public Health, 11(1), 2013, 249-270.

5.STALDER, T., BARRAUD, O., JOVE, T., CASELLAS, M., GASCHET, M., DOGOT, C., PLOY, M.C., Quantitative and qualitative impact of hospital effluent on dissemination of the integrin pool, The ISME Journal, 2014, 768-777.

6.CHITNIS, V., CHITNIS, S., VAIDYA, K., RAVIKANT, S., PATIL, S., CHITNIS, D.S., Bacterial population changes in hospital effluent treatment plant in central India, Water Res., 38(2), 2004, 441447.

7.CATRANGIU, A., NICULESCU, D., LUCACIU, I., CHIFIRIUC, C., MIHAESCU, G., Virulence factors of Gram negative bacteria isolated from natural aquatic ecosystems, J. Environ. Prot. Ecol., 16(1), 2015, 33-39.

8.***SR EN ISO 19458 - Water quality. Sampling for microbiological analysis.

9.***SR EN ISO 9308-2 - Water quality. Enumeration of Escherichia coli and coliform bacteria. Part 2: Most Probable Number method.

10.STOICA, S., VASILE, G.G., BANCIU, A.R., NICULESCU, D., LUCACIU, I., LAZAR, M.N., Influence and anthropogenic pressures on groundwater quality from rural area, Rev. Chim., 69(8), 2017, 1744-1748.

11.STOICA, C., ANCUTA, P.N., LUCACIU, I.E., BANCIU, A.R., SOREA, S., ATANASESCU, A., LAZAR, M.N., Computerized high-tech detection technology of immunofluorescence labelled waterborne pathogenic bacteria, Rev. Chim., 69(11), 2018, 4166-4170.

12.NITA-LAZAR, M., GALAON, T., BANCIU, A., PAUN, I., STOICA, C., LUCACIU, I., Screening of various harmful compounds in a new bacterial biological model, J. Environ. Prot. Ecol., 17(1), 2016, 237-247.

Manuscript received: 12.12 .2019 